\title{
Exploring Antecedents of Service Innovation Excellence in Manufacturing SMEs
}

Citation for published version (APA):

Mennens, K., van Gils, A., Odekerken - Schröder, G., \& Letterie, W. (2016). Exploring Antecedents of Service Innovation Excellence in Manufacturing SMEs. Maastricht University, Graduate School of Business and Economics. GSBE Research Memoranda No. 025 https://doi.org/10.26481/umagsb.2016025

Document status and date:

Published: 01/01/2016

DOI:

10.26481/umagsb.2016025

Document Version:

Publisher's PDF, also known as Version of record

\section{Please check the document version of this publication:}

- A submitted manuscript is the version of the article upon submission and before peer-review. There can be important differences between the submitted version and the official published version of record.

People interested in the research are advised to contact the author for the final version of the publication, or visit the DOI to the publisher's website.

- The final author version and the galley proof are versions of the publication after peer review.

- The final published version features the final layout of the paper including the volume, issue and page numbers.

Link to publication

\footnotetext{
General rights rights.

- You may freely distribute the URL identifying the publication in the public portal. please follow below link for the End User Agreement:

www.umlib.nl/taverne-license

Take down policy

If you believe that this document breaches copyright please contact us at:

repository@maastrichtuniversity.nl

providing details and we will investigate your claim.
}

Copyright and moral rights for the publications made accessible in the public portal are retained by the authors and/or other copyright owners and it is a condition of accessing publications that users recognise and abide by the legal requirements associated with these

- Users may download and print one copy of any publication from the public portal for the purpose of private study or research.

- You may not further distribute the material or use it for any profit-making activity or commercial gain

If the publication is distributed under the terms of Article $25 \mathrm{fa}$ of the Dutch Copyright Act, indicated by the "Taverne" license above, 
Kars Mennens, Anita van Gils, Gaby Odekerken-Schröder, Wilko Letterie

\section{Exploring Antecedents of} Service Innovation Excellence in Manufacturing SMEs

RM/16/025

\section{GSBE}

Maastricht University School of Business and Economics

Graduate School of Business and Economics

P.O Box 616

NL-6200 MD Maastricht

The Netherlands 


\title{
Exploring Antecedents of Service Innovation Excellence in Manufacturing SMEs
}

Kars Mennens, Anita van Gils, Gaby Odekerken-Schröder \& Wilko Letterie

\begin{abstract}
Servitization is a process of creating value by shifting from merely selling products to selling solutions that integrate products and services. It is a strategy often used by manufacturing SMEs to avoid or escape the commodity trap. Research has illustrated that servitization can lead to a competitive advantage in the marketplace, but many SMEs still fail to servitize successfully. In this paper, we discuss factors that enable SMEs to achieve service innovation excellence. Using a knowledge based-perspective, we posit that absorptive capacity, which is the ability to identify, assimilate and exploit external knowledge, is one of these critical factors. Additionally, we investigate the effect of two potential drivers that can influence absorptive capacity, namely employee collaboration and an SME's search breadth. Our findings, resulting from survey research on a sample of Dutch manufacturing SMEs, confirm that employee collaboration and search breadth have a positive effect on the organization's absorptive capacity, which in turn is a driver of service innovation excellence. These results have implications for theory development on servitization and provide SMEs with insights on how to successfully servitize.
\end{abstract}

Keywords: service innovation excellence, absorptive capacity, search breadth, employee collaboration, servitization 


\section{Introduction}

An increasing amount of organizations in the manufacturing industry suffers from a phenomenon that is called the commodity trap. It implies that the selling price of their products is calculated based on the cost of production instead of on the potential added value of the offer to their clients. Due to intensifying competition, the wide distribution of manufacturing and business process knowledge, production in low-cost areas and the shorter amount of time a product lasts in the market before it is replaced by a newer and improved product (Chesbrough, 2011), this type of strategy results in price pressures and decreasing product margins (Gebauer, Fleisch \& Friedli, 2005). As a result, more and more manufacturing companies have started to integrate services as a distinctive factor in their competitive strategy (Gebauer, Fleisch \& Friedli, 2005).

The process of creating value by shifting from merely selling products to selling solutions that integrate products and services is called "servitization" (Baines, Lightfoot, Benedettini \& Kay, 2009). Whereas servitizing manufacturing companies are constantly seeking to provide better services (Berry, Shankar, Turner Parish, Cadwallader \& Dotzel, 2006), most firms consider it difficult to achieve service innovation excellence, which is the firm's achievement in realizing a service innovation-based competitive advantage. As a result, many firms fail to achieve the expected benefits of servitization (Spring \& Araujo, 2009; Gebauer et al., 2005). Next to this, research acknowledges that servitization necessitates higher investments and therefore might increase the firm's risk of failure and bankruptcy (Gebauer et al., 2005).

The difficulties and risks associated with the increased investments in service innovation are articulated especially for SMEs, as this group of companies tends to have fewer resources available for innovation than larger organizations (Terziovski, 2010). Next to this, SME owner-managers have a dominant position in the strategic development of these 
firms, and their cognitive and affective characteristics can lead to imprinting effects on the full organization (Hermann and Nadkarni, 2014; Zhang et al., 2006). This might result in a quasi lock-up situation in which the renewal of routines and capabilities is hampered (Liao et al., 2008). Additionally, about seventy percent of the SMEs are family businesses, in which socio-emotional wealth preservation often is prioritized over business renewal (GómezMejía, et al., 2007). Problems with regards to changing innovation routines towards servitization are aggravated for manufacturing SMEs, as these firms traditionally achieve competitive advantages through product innovation (e.g. Fuchs et al., 2000; Terziovski, 2010; Freel, 2000; Madrid-Guijarro, Garcia \& Van Auken, 2009; Raymond \& St-Pierre, 2010; Maes \& Sels, 2014). Although some antecedents are the same for both service as well as product innovation, the key capabilities required for success are clearly distinct (Nijssen et al., 2006, Storey et al., 2015).

So far, the majority of innovation studies focused on products, resulting in a paucity of studies on service innovations (Page and Schirr, 2008), but recently, an increasing number of studies have started to identify the factors underlying service innovation excellence (Storey et al., 2015). Service quality and proficient operations and delivery systems drive service innovation excellence by augmenting the service offering (Storey and Easingwood, 1998). Furthermore, innovation culture and innovation strategy are key success factors of service innovation, by ensuring that the development of new services is a priority (Storey et al., 2015). Closely related is the importance of organizational design practices such as reward structures (Atuahene-Gima, 1996). The involvement of front-line staff is also recognized as a critical determinant of service innovation excellence (De Brentani, 1989).

Next to these factors, knowledge from customers (Carbonell et al., 2009; Melton \& Hartline, 2010) and other external relations (Storey et al., 2015) is an important antecedent of service innovation excellence. This is in line with the service-dominant logic, the leading perspective 
in services research, in which it is stated that knowledge is the most important resource to achieve both service innovation and a competitive advantage based on services (Lusch, Vargo \& O’Brien, 2007). This knowledge can be acquired from both internal and external sources (Volberda, Foss \& Lyles, 2010). When compared to product innovation, which depends more on knowledge that is created by internal R\&D excellence, service innovation excellence is more often achieved by utilizing external knowledge (Storey et al., 2015). However, the utilization of external knowledge will only result in innovation performance if the knowledge acquired from internal and external sources can be assimilated and transformed into valuable knowledge for the firm (Escribano, Fosfuri \& Tribó, 2009). The capability to recognize and assimilate valuable external knowledge, and apply it to commercial ends is called absorptive capacity (Cohen \& Levinthal, 1990). Previous research established that absorptive capacity is a driver of product innovation (e.g. Tsai, 2001; Chen, Lin \& Chang, 2009; Fosfuri \& Tribó, 2008; Alegra, Sengupta \& Lapiedra, 2013). Due to the aforementioned different antecedents of successful product and service innovation, it cannot simply be assumed that ACAP also leads to service innovation excellence. The meta-analysis by Storey et al. (2015) is the first research to suggest that there is a link between ACAP and service innovation excellence. To the best of our knowledge, an empirical link between absorptive capacity and service innovation excellence has not yet been established. Therefore, it is important to develop theory and further enhance our understanding of how absorptive capacity impacts service innovation excellence (Storey et al., 2015). The objective of this study is to investigate the effect of ACAP on service innovation excellence, defined as the firm's achievement in realizing a service-based competitive advantage, in a sample of Dutch servitizing manufacturing SMEs. We do this by taking a knowledge-based perspective and using the dynamic capabilities theory. 
Additionally, if ACAP appears to be a key driver of service innovation excellence, it is important to discover the antecedents of ACAP in SMEs. Literature suggests that translating external knowledge into new services, in other words, the ACAP process, requires dynamic interactions both within and outside the firm (Chirico \& Nordqvist, 2010). Therefore, we also investigate the effects of employee collaboration, which is the extent to which personnel are engaged in the service innovation process, and search breadth, the degree of diversity of external innovation partners.

This research contributes to the literature in several ways. First, we advance the theory on service innovation performance by investigating whether ACAP is an antecedent of service innovation excellence. It is widely recognized that there is a scarcity of research on service innovation compared to the research on product innovation, especially in an SMEcontext (Chen, Damanpour \& Reilly, 2010; Page \& Schirr, 2008). Second, we provide evidence that, even though servitization requires a major shift in the mindset of an organization, the importance of building a knowledge base is as important for service innovations as it is for product innovations. Third, we contribute to the ACAP literature by identifying search breadth and employee collaboration as antecedents. Fourth, by investigating how manufacturing SMEs can achieve service innovation excellence we further develop the servitization literature.

The remainder of this paper is structured as follows: First, we review the existing literature and derive our hypotheses. Next, the sample, measures and data analysis will be described in the methods sections. Finally, we present and discuss our results and implications and suggest avenues for future research. 


\section{Literature Review \& Hypotheses}

In this section, we will explain the theoretical underpinnings and hypotheses of this research. As noted before, we will use a knowledge-based view and dynamic capabilities theory to develop the theoretical framework. The knowledge-based view considers knowledge to be the most important resource of the organization and the key determinant of a competitive advantage (Kogut \& Zander, 1992). The vital role of knowledge is also acknowledged in services research (Vargo \& Lusch, 2004). This makes ACAP a highly relevant construct when researching service innovation excellence, as ACAP is essential to developing and increasing a firm's knowledge base (Volberda, Foss \& Lyles, 2010).

\subsection{Absorptive Capacity}

ACAP has traditionally been defined as "the ability to recognize the value of new information, assimilate it, and apply it to commercial ends" (Cohen \& Levinthal, 1990, p. 128). ACAP entails using external knowledge to foster internal innovation (Flatten, Greve \& Brettel, 2011). It develops cumulatively, is path-dependent and builds on existing knowledge (Cohen \& Levinthal, 1994). In previous research, ACAP has often been used as an antecedent of innovation performance (Gebauer, Worch \& Tröffer, 2012). For example, it has been shown that developing and maintaining ACAP is vital to a firm's long-term viability and fosters product innovation (Zahra \& George, 2002; Tsai, 2001). Maes and Sels (2014) identified absorptive capacity as a driver of radical product innovation in SMEs, and Tzokas, Kim, Akbar and Al-Dajani (2015) found that an SME's ACAP leads to better performance in terms of new product development. Surprisingly, very little attention has been paid to the effect that ACAP has on service innovation performance so far, despite meta-analytical 
findings that indicate that ACAP is one of the most important success factors of service innovation excellence (Storey et al, 2015).

Initially, Cohen and Levinthal (1990) introduced three sequential processes of ACAP, namely, identification, assimilation and exploitation. ACAP has been reconceptualized multiple times thereafter. In this research, we follow the approach advanced by Zahra and George (2002). They propose ACAP as a dynamic capability embedded in a firm's routines and processes, which requires investments in order to develop (Volberda, Foss \& Lyles, 2010). The extent to which ACAP is developed causes the differences in a firms' ability to create and sustain a competitive advantage (Flatten, Greve \& Brettel, 2011). ACAP consists of four complementary dimensions that build upon each other to produce a dynamic organizational capability (Zahra \& George, 2002): acquisition; assimilation; transformation; and exploitation. Acquisition refers to the capability to discover and obtain external information that is relevant to the organization. It refers to whether an organization knows where potential sources of information are (Fosfuri \& Tribó, 2008). The assimilation dimension refers to the organization's routines and processes that allow it to analyse, process, interpret and comprehend the information that was obtained from external parties.

Transformation entails the ability to modify and adapt the external knowledge in such a way that it can be combined with existing internal knowledge. Exploitation refers to the ability to utilize the transformed knowledge into an organization's operations.

Zahra \& George (2002) divided the ACAP process into two sections, namely: potential ACAP (PACAP) and realized ACAP (RACAP). PACAP consists of the first two dimensions acquisition and assimilation, whereas RACAP comprises the last two dimensions transformation and exploitation. Being able to translate external knowledge into new services requires dynamic interactions both within and outside the organization's boundaries (Chirico 
\& Nordqvist, 2010). Therefore, we propose employee collaboration in the innovation process and search breadth, which is the diversity of innovation partners, as antecedents of ACAP.

\subsection{Absorptive Capacity \& Employee Collaboration}

Jansen, Van den Bosch \&Volberda (2005) find that employee participation in decision making has a positive influence on an organization's PACAP by enhancing its acquisition and assimilation capabilities. This can be attributed to the increased number of employees that act as "receptors" to the environment that are taken into consideration if they participate in the innovation process (Cohen \& Levinthal, 1990). These receptors scan their external environment and consequently filter and facilitate the acquisition of new external knowledge (Aldrich \& Herker, 1977). The effects of participation in decision making, or in other words collaboration with employees, are even more significant in the service innovation domain, as contact personnel is considered as the most important interface for external knowledge in this domain (Atuahene-Gima, 1996). Collaboration with service employees has been found to increase the amount of information collected concerning customer problems (Kelley, 1993). Furthermore, contact employees are important internal organizational resources that the firm uses to gather and assess information that is needed to create successful new services (Melton \& Hartline, 2013).

Next to this, it appears that employee participation in decision making impacts an organization's RACAP by increasing the transformation and exploitation capabilities of new external knowledge (Jansen, Van den Bosch \& Volberda, 2005). This can be explained by Cohen and Levinthal's (1990) argument that interactions across individuals with diverse and different knowledge structures will augment the organization's capacity for making novel linkages and associations. In other words, interactions between employees who possess 
varying knowledge will improve the organization's ability to transform external knowledge. In fact, the external knowledge that has been absorbed cannot be effectively utilized without the ability to internally share this knowledge (Benson \& Ziedonis, 2009; Rothaermel \& Alexandre, 2009). Next to this, Schneider and Bowen (1984) argue that collaboration with contact employees facilitates innovation implementation. It allows the organization to utilize the external information to create successful new services (Melton \& Hartline, 2012). Thus, employee collaboration increases the ability of an organization to both transform and exploit external knowledge.

Collaboration with employees enhances the ability to understand external environmental trends (Lusch, Vargo \& O’Brien, 2007). In specific, contact employees are key to gathering, enabling, interpreting, disseminating and acting on relevant external knowledge to develop and offer service innovations that provide a competitive advantage (Melton \& Hartline, 2012). This suggests that employee collaboration has a positive influence on all dimensions of ACAP. Therefore:

H1A: Employee collaboration positively influences an SME's PACAP.

H1B: Employee collaboration positively influences an SME's RACAP.

\subsection{Absorptive Capacity \& Search Breadth}

R\&D-cooperation and inter-firm relationships have been identified as antecedents of ACAP (Cohen \& Levinthal, 1990; Fosfuri \& Tribó, 2008; Zahra \& George, 2002). Gaining knowledge from external sources and learning from partners are critical parts of the interorganizational antecedents of ACAP (Volberda, Foss \& Lyles, 2010). The greater the interaction with external knowledge sources, the larger the experiential learning that is accumulated by the organization. Openness to external sources allows organizations to 
identify and acquire ideas in the external environment and increases the opportunities available to them, whereas too much of an internal focus may result in missing opportunities (Laursen \& Salter, 2006). The breadth of outside knowledge exposure has a positive influence on a firm's propensity to acquire external knowledge (Van Wijk, Van den Bosch \& Volberda, 2001) Organizations use the knowledge from different external partners for different purposes (Teece, 1980). As having cooperated with a greater diversity of external partners will result in better abilities to acquire and assimilate knowledge from these diverse partners, we hypothesize that a greater search breadth will result in better developed acquisition and assimilation capabilities.

H2: Search breadth positively influences an SME's potential absorptive capacity.

\subsection{Absorptive Capacity and Service Innovation Excellence}

Although acquisition and assimilation are necessary to identify, capture and process relevant external knowledge, ACAP will only lead to a competitive innovation advantage if the knowledge is subsequently transformed and exploited (Fosfuri \& Tribó, 2008). Being able to understand important trends and know-how from the external environment ensures that the external environment can be used as an important knowledge resource (Lusch et al., 2007). For example, scientific knowledge from a university or research institute can facilitate the identification of a new target market or market segment, or it can be a source of radical innovation ideas (Tether, 2002). Furthermore, the scientific knowledge can make SME management aware of the possibilities of new business models and technological developments (Bishop, D’Este \& Neely, 2011). Such knowledge allows firms to better address customer needs and supports a faster response to market opportunities (Slater \& Narver, 1995). Next to this, knowing about customer needs leads to a higher service quality 
(Voss et al., 1992), whereas competitor knowledge can be a source for benchmarking and best practices (Drew, 1997). Exploiting this external knowledge is a fundamental source of competitive advantage with service innovations (Lusch, Vargo \& O’Brien, 2007). In short, firms succeed in their service innovation efforts by utilizing external knowledge (Storey et al., 2015). Therefore, we pose that being able to transform and exploit external knowledge has a positive effect on service innovation excellence.

H3: An SME's RACAP positively influence Service Innovation Excellence

--- Figure 1 here ---

\section{Research methodology}

\subsection{Sample and data characteristics}

The items that measure the constructs of this study were included in a larger questionnaire that evaluated the innovativeness of manufacturing SMEs. Data was collected by surveying Dutch manufacturing SMEs in the southern provinces of the Netherlands. An organization was acknowledged as an SME if it had up to 250 employees, which is in line with the European Union definition. The questionnaire was first sent to 1711 SME's via e-mail, which contained a link to an online survey. In case we did not receive an answer, a reminder was sent. If after this still no response was acquired, we sent a reminder letter by mail, which included a reply envelope. In total, a number of 246 organizations answered the survey, accounting for a response rate of 14,4 percent, which is considered normal for this type of research (Baum, Locke and Smith, 2001; Moreno and Casillas, 2008; Wiklund and Shepherd, 2005; Zahra and Garvis, 2000). After deleting 53 observations because of missing values or because of not meeting our sample criteria, we obtained a dataset with 193 respondents. 
Thereafter, it was checked which respondents indicated that they had implemented at least one service innovation in the past year. This provided us a final dataset with 97 respondents. Nonresponse bias was taken care of by testing the difference between early and late responses (Armstrong and Overton, 1977). A t-test was conducted to check for this difference. For all relevant variables, no significant differences were found at the 0.05 significance level.

\subsection{Measures}

Antecedents of Absorptive Capacity. Similar to previous research by Laursen and Salter (2006) and Classen, Van Gils, Bammens and Carree (2012), search breadth is defined as the number of external partners that organizations cooperate with in the context of innovation. Five types of external innovation partners were included in our questionnaire, namely customers, suppliers, competitors, universities or knowledge institutions and the public sector or government. These five items were coded as binary variables, where a value of 1 means making use of this type of external innovation partner, and 0 means not making use of this type of external innovation partner. Search breadth was then calculated by adding up these five binary variables. The 3-item scale of Ordanini and Parasuraman (2010), which intends to measure the extent to which contact personnel is engaged in the service innovation process, was adapted to represent in how far employees are participating in the development of new strategies, priorities and services. A survey item was: "Employees are actively engaged in establishing goals and priorities for our strategies."

Absorptive Capacity. Muscio (2007) and Volberda, Foss and Lyles (2010) pose that there is no consensus among researchers about how to conceptualize and measure ACAP. As ACAP was classically measured by taking R\&D as a proxy (Cohen \& Levinthal, 1989; Zahra \& George, 2002), this conceptualization and measurement problem is particularly articulated for 
SMEs, where R\&D activity is generally low (Brouwer \& Kleinknecht, 1997). Jansen, Van den Bosch and Volberda (2005) developed a scale to measure the conceptualization of absorptive capacity by Zahra and George (2002). They distinguish between PACAP and RACAP. PACAP consists of an acquisition and assimilation dimension, whereas RACAP is constituted by a transformation and exploitation dimension. Jansen et al. (2005) demonstrate that although acquisition and assimilation form PACAP together, the two dimensions are clearly distinct. Because acquisition and assimilation do not share a high mutual correlation and both measure a different capability, PACAP is presented as a formative, second-order construct in this research (Becker, Klein \& Wetzels, 2012). The same logic applies to RACAP. We decided to use the scale by Jansen et al. (2005), but to exclude three items of the acquisition dimension because these items did not fit the SME-context of this research. As a result, acquisition and assimilation were both measured by three items, whereas the transformation and exploitation dimensions were measured by six items. A sample item for assimilation was: "New opportunities to serve our clients are quickly understood.", whereas a sample item for exploitation was: "We constantly consider how to better exploit knowledge."

Service Innovation Excellence. We operationalized service innovation excellence by using the scales from Carbonell, Rodríguez-Escudero and Pujari (2009), who adapted de Brentani's (1989) measurement scales in order to assess the competitive superiority of new services. Three items measured on a 7-point Likert scale measured the performance of service innovations that were actually brought to the market. Sample items include "Our customer solutions are superior to those of our competitors" and "Our new services give us an important competitive advantage." Table 1 shows the full list of items used to assess employee collaboration, ACAP and service innovation excellence. 
Firm Age. This variable was included as a control variable to account for differences in firm age, as existing research shows that older firms demonstrate less innovation activities (Huergo \& Jamandreu, 2004).

--- Table 1 here ---

\subsection{Method of analysis}

Partial Least Squares Structural Equation Modeling (PLS-SEM) was used to test the model and hypotheses. PLS is a multivariate analysis technique that enables the researcher to examine latent and manifest variables simultaneously (Fornell, 1987). It is widely acknowledged that PLS can effectively deal with small sample sizes and handle non normal data (Chin, 1998). Most importantly, it can handle both reflective and formative constructs (Henseler, Ringle, \& Sinkovics, 2009). In specific, SmartPLS 3.0 was used to conduct the analyses (Ringle, Wende \& Becker, 2015). The assessment of the model is conducted in two steps. In the first step the measurement model, or outer model, which connects manifest variables to their latent variables, is evaluated. In the second step the structural model, showing the relationships between latent variables, is tested (Hulland, 1999; Fornell \& Larcker, 1981).

\section{Results}

\subsection{Measurement Model}

To obtain construct reliability, we check the item loadings and composite reliability. First, the individual item reliability is examined by looking at the loadings. According to Hulland 
(1999), it is common to find that several items in an estimated model have loadings below the generally accepted 0.7 threshold, and that in general item loadings of above 0.4 are acceptable. After careful consideration, two items with a loading below 0.4 were deleted for the transformation dimension, and three items were deleted for the exploitation dimension. All the other items were retained. To establish construct reliability, Hair, Sarstedt, Ringle and Mena (2012) state that it is preferred to rely on the composite reliability score for PLS-SEM research, even though Cronbach's alpha is the most common measure of internal consistency reliability. This is the case because unlike Cronbach's alpha, composite reliability does not assume that all indicators are equally reliable (Hair, Ringle \& Sarstedt, 2011). It can be seen from table 1 that for all latent variables the composite reliability is above 0.7 , which is the recommended threshold.

Convergent validity is assessed by the average variance extracted (AVE), which should be above 0.5 (Bagozzi \& Yi, 1988). With the lowest AVE being 0.51, this condition is satisfied for all relevant constructs. These values for composite reliability and AVE imply that the internal consistency of each construct is sufficient. To ensure that discriminant validity is present, each construct must share more variance with its measures than with the other constructs. This is the case if the square root of the AVE of each construct is higher than the correlations with the other constructs (Fornell \& Larcker, 1981). Next to this, the square root of the AVE has to have a value of at least 0.7 (Chin, 1998). Table 2 shows that this is the case for all constructs, which implies that there is discriminant validity.

The second-order formative construct ACAP was assessed by testing for multicollinearity of its formative indicators, which in this case were the first-order reflective constructs acquisition, assimilation, transformation and exploitation (Diamantopoulos, Riefler \& Roth, 2008; Henseler, Ringle \& Sinkovic, 2009). The VIF values did not exceed 1.85, which is far below the commonly accepted threshold of 10 (Diamantopoulos, Riefler \& Roth, 
2008). Furthermore, the formative indicators were all significant with weights between 0.42 and 0.76 . Therefore, the validity of the second-order formative construct is verified.

Now that the conditions for the measurement model have been satisfied, we turn our focus towards the structural model, which deals with the relationships between the constructs.

--- Table 2 here ---

--- Table 3 here ---

\subsection{Structural Model}

The appropriateness of the structural model is assessed on the basis of the $\mathrm{R}^{2}$ values of the dependent variables. Falk and Miller (1992) determined that $\mathrm{R}^{2}$ is sufficient when its value is equal to or exceeds 0.1 . According to figure 2 , the $\mathrm{R}^{2}$ values of 0.32 for PACAP, 0.27 for RACAP and 0.22 for service innovation excellence are well above this threshold. Following Hair, Ringle and Sarstedt (2011), the significance of the coefficients was estimated by using 5000 bootstrap samples.

The first hypothesis (H1A), which posited that employee collaboration has a positive influence on an SME's PACAP, is confirmed by the results of our study $(\beta=0.393, \mathrm{p}<$ 0.001). Similarly, as predicted by hypothesis H1B, the results indicate that employee collaboration indeed has a positive effect on an SME's RACAP $(\beta=0.314, p<0.01)$.

Consistent with hypothesis 2, our findings suggest that an SME's search breadth is positively related to an SME's PACAP $(\beta=0.325, \mathrm{p}<0.001)$. The final hypothesis $(\mathrm{H} 3)$ predicted that an SME's RACAP has a positive effect on service innovation excellence. This is confirmed by the results of this study $(\beta=0.326, \mathrm{p}<0.05)$. 
--- Figure 2 here ---

\section{Discussion}

Today, manufacturing SMEs face the challenge of avoiding or breaking out of the commodity trap (Chesbrough, 2011). As a solution, SMEs in the manufacturing industry are increasingly focusing on servitization strategies (Gebauer, Fleisch \& Friedli, 2005). However, despite constant efforts of providing successful service innovations, most fail to deliver service innovations effectively and do not achieve the expected servitization benefits (Neely, 2008). Because service innovations represent an important way to retain or gain a competitive advantage, it is important to discover how manufacturing SMEs can successfully deliver service innovations. In this study we empirically test and advance the theory on whether ACAP is an important antecedent of service innovation excellence in SMEs. Next to this, we investigated whether search breadth and employee collaboration are drivers of ACAP

We find support for all of our hypotheses. Collaboration with employees in the innovation process augments all dimensions of an SMEs' absorptive capacity, while a larger diversity of innovation partners has a positive impact on the SME's potential absorptive capacity. Next to this, utilizing external knowledge through an SME's RACAP has a positive effect on service innovation excellence. In other words, a manufacturing SME can achieve service innovation excellence if it has the capability to transform and exploit relevant external knowledge it has acquired and assimilated.

Our research offers several contributions to theory. First, we contribute to the scarce literature on service innovation by establishing an empirical link between ACAP to a and service innovation excellence in an SME context. We thereby found empirical support to confirm the suggestion by Storey et al. (2015) that ACAP is an important antecedent of 
service innovation excellence. Second, we contribute to the debate discussing whether successful servitization requires a radical change in the way organizations think about their operations and value delivery (Gaiardelli, Martinez \& Cavalieri, 2015). Because many organizations fail to successfully servitize and key factors that lead to product innovation excellence are different from those that lead to service innovation success (Nijssen et al., 2006), some researchers emphasize that servitization demands a new mindset, operations and strategies. For example, Storey et al. $(2015$, p. 19) claim that "servitizing manufacturing firms need to adapt their innovation practices and capabilities to recognize the differences between services and products." Without denying the differences between service and product innovation, our results demonstrate that the same knowledge mechanism is an important driver of both types of innovation. Where previous research already showed a positive influence of ACAP on product innovation (Tsai, 2001; Chen, Lin \& Chang, 2009; Fosfuri \& Tribó, 2008; Alegra, Sengupta \& Lapiedra, 2013), our results indicate that ACAP is a driver of service innovation excellence as well. This implies that the importance of developing and increasing the firm's knowledge base does not necessarily change in the servitization process of manufacturing SMEs. The main difference resides in the nature of external knowledge that is acquired, assimilated, transformed and exploited. As services are intangible, knowledge will more often be tacit and difficult to manage (Blindenbach-Driessen \& Van den Ende, 2014; Johne \& Storey, 1998). Third, we advance the theory on ACAP by identifying employee collaboration and search breadth as important antecedents of service innovation excellence. Finally, by researching how manufacturing SMEs can achieve service innovation excellence we further our understanding of how SMEs can servitize successfully.

Our findings have implications for SME management and policy makers. Manufacturing organizations often face the commodity trap, and existing literature states that focusing on servitization is the best strategy for manufacturing organizations to escape this 
(Chesbrough, 2011). However, at the same time the expected financial and strategic benefits of servitization are often not achieved (Neely, 2008; Gebauer, Fleisch \& Friedli, 2005). We show that servitizing manufacturing SMEs seeking to outperform competition by means of service innovation need to develop or enhance their absorptive capacity. Further, having employees that can actively participate in the service innovation process as well as increasing the diversity of external partners used for innovation appear to be explicit means to develop absorptive capacity and to indirectly achieve service innovation excellence.

Service innovations can help firms retaining their competitive advantage as products become increasingly commoditized (Chesbrough, 2011). In other words, subsidies that are aimed at stimulating service innovation represent an opportunity for policy makers to strengthen the local manufacturing industry. This research shows that investing in an SME's capacity to acquire, assimilate, transform and exploit external knowledge is an effective way to spur service innovation excellence. In specific, organizing network events and awareness sessions where SME managers can discuss cooperation possibilities with customers, suppliers, competitors, universities and the local government could be a way in which the acquisition and assimilation dimensions of ACAP are developed. Next to this, workshops or training programmes in which employees from all departments and layers of the SME are encouraged to collectively work on an innovation case could demonstrate the power of employee collaboration in the innovation process. This could result in organization-wide involvement in innovation efforts, thereby developing all dimensions of ACAP.

Our study also has several limitations. First, the survey methodology might have created a common method bias. This can inflate the relationships between the constructs, especially when respondents are aware of the conceptual framework of interest (Sousa, Lengler \& Martínez-López, 2014). However, in this research the respondents were not informed about the conceptual model of this research and could therefore not provide 
answers based on their beliefs on how the variables should relate to each other. Next to that, the variables of interest were separated in the survey by several items measuring constructs that are not relevant in this research. Second, we relied on subjective performance data. This was necessary because for most SMEs there is no public performance data available. The subjective data should however be a minor concern as the executives who filled in the surveys are the best knowledgeable source of firm-level information (Noburn \& Birley, 1988). The third limitation is the cross-sectional nature of the data, which limits our ability to verify causal relationships. Longitudinal data would have allowed us to test for causality. Finally, this study is based on a sample that only consists of Dutch manufacturing SMEs. This limits the generalizability of our results due to cultural differences (Hofstede, 1993). For instance, in the Netherlands, power distance is relatively low, which implies that employees expect to be consulted by their superiors when it comes to decision making. As a result, collaborating in the innovation process is more natural to Dutch employees. To the contrary, in an Asian context, power distance is much higher, and subordinates are expecting to be told what to do instead of being consulted. These limitations offer fruitful avenues for future research. Researching the effect of ACAP on other performance measures of service innovation in a longitudinal study with a different cultural context would further improve our understanding of the relationship between ACAP and service innovation excellence. 


\section{References}

Alam, I. (2002). An exploratory investigation of user involvement in new service development. Journal of the Academy of Marketing Science, 30(3), 250-261.

Aldrich, H., \& Herker, D. (1977). Boundary spanning roles and organization structure. Academy of Management Review, 2(2), 217-230.

Alegra, J., Sengupta, K., \& Lapiedra, R. (2013). Knowledge management and innovation performance in a high tech SMEs industry. International Small Business Journal, 31(4), 454-470.

Armstrong, J., \& Overton, T. (1977). Estimating nonresponse bias in mail surveys. Journal of Marketing Research, 396-402.

Atuahene-Gima, K. (1996). Differential Potency of Factors Affecting Innovation Performance in Manufacturing and Services Firms in Australia. Journal of Product Innovation Management, 13(1), 35-52.

Audia, P., \& Greve, H. (2006). Less likely to fail: Low performance, firm size and factory expansion in the shipbuilding industry. Management Science, 52(1), 83-94.

Bagozzi, R., \& Yi, Y. (1988). On the evaluation of structural equation models. Journal of the Academy of Marketing Science, 16(1), 74-94.

Baines, T., Lightfoot, H., Benedettini, O., \& Kay, J. (2009). The servitization of manufacturing: A review of literature and reflection on future challenges. Journal of Manufacturing Technology, 20(5), 547-567.

Barclay, D., Higgins, C., \& Thompson, R. (1995). The partial least squares (PLS) approach to causal modeling: Personal computer adoption and use as an illustration [Special issue on research methodology]. Technology Studies, 2(2), 285-309.

Baum, J., Locke, E., \& Smith, K. (2001). A multidimensional model of venture growth. Academy of Management Journal, 44(2), 292-303.

Becker, J., Klein, K., \& Wetzels, M. (2012). Hierarchical latent variable models in PLS-SEM: guidelines for using reflective-formative type models. Long Range Planning, 45(5), 359-394.

Benson, D., \& Ziedonis, H. (2009). Corporate venture capital as a window on new technologies: Implications for the performance of corporate investors when acquiring startups. Organization Science, 20(2), 329-351.

Berry, L., Shankar, V., Parish, J., Cadwallader, S., \& Dotzel, T. (2006). Creating New Markets Through Service Innovation. MITSloan Management Review, 47(2), 56-63.

Bishop, K., D'Este, P., \& Neely, A. (2011). Gaining from interactions with universities: Multiple methods for nurturing absorptive capacity. Research Policy, 40, 30-40.

Bishop, K., D'Este, P., \& Neely, A. (2011). Gaining from interactions with universities: Multiple methods for nurturing absorptive capacity. Research Policy, 40(1), 30-40.

Blindenbach-Driessen, F., \& Ende, J. (2014). The locus of innovation: The effect of a separate innovation unit on exploration, exploitation and ambidexterity in manufacturing and service firms. Journal of Product Innovation Management, 31(5), 1089-1105. 
Bollen, A. (1989). Structural equations with latent variables. New York: Wiley.

Bolton, M. (1993). Organizational innovation and substandard performance: When is necessity the mother of innovation? Organization Science, 4(1), 57-75.

Bromiley, P. (1991). Testing a causal model of corporate risk taking and performance. Academy of Management Journal, 34(1), 37-59.

Brouwer, E., \& Kleinknecht, A. (1997). Measuring the unmeasurable: a country's non-R\&D expenditure on product and service innovation. Research policy, 25(8), 1235-1242.

Carbonell, P., Rodríguez-Escudero, A., \& Pujari, D. (2009). Customer involvement in new service development: An examination of antecedents and outcomes. Journal of Product Innovation Management, 26(5), 536-550.

Cepeda-Carrion, G., Cegarra-Navarro, J., \& Jimenez-Jimenez, D. (2012). The effect of absorptive capacity on innovativeness: Context and information systems capability as catalysts. British Journal of Management, 23(1), 110-129.

Chen, J., Damanpour, F., \& Reilly, F. (2010). Understanding antecedents of new product development speed: A meta-analysis. Journal of Operations Management, 28, 17-33.

Chen, W. (2008). Determinants of firm's backward- and forward-looking R\&D search behavior. Organization Science, 19(4), 609-622.

Chen, Y., Lin, M., \& Chang, C. (2009). The positive effects of relationship learning and absorptive capacity on innovation performance and competitive advantage in industrial markets. Industrial Marketing Management, 38(2), 152-158.

Chesbrough, H. (2011). The case for open services innovation: The commodity trap. California Management Review, 53(3), 5-20.

Chin, W. (1998). The Partial Least Squares Approach to Structural Equation Modelling. In G. Marcoulides (Ed.), Modern Methods for Business Research (pp. 295-336). Mahwah, NJ: Lawrence Erlbaum.

Chirico, F., \& Nordqvist, M. (2010). Dynamic capabilities and trans-generational value creation in family firms: The role of organizational culture. International Small Business Journal, 28(5), 487-504.

Chrisman, J., \& Patel, P. (2012). Variations in R\&D investments of family and nonfamily firms: Behavioral agency and myopic loss aversion perspectives. Academy of Management Journal, 55(4), 976-997.

Classen, N., Van Gils, A., Bammens, Y., \& Carree, M. (2012). Accessing resources from innovation partners: The search breadth of family SMEs. Journal of Small Business Management, 50(2), 191-215.

Cohen, W., \& Levinthal, D. (1990). Absorptive capacity: A new perspective on learning and innovation. Administrative Science Quarterly, 35, 128-152.

Cohen, W., \& Levinthal, D. (1994). Fortune favors the prepared firm. Management Science, 40(2), 227-251. 
Cooper, R. (2001). Winning at new products. Accelerating the process from idea to launch. Cambridge, MA: Perseus.

Cyert, R., \& March, J. (1963). A behavioral theory of the firm. Englewood Cliffs, NJ.

Diamantopoulos, A., \& Winklhofer, H. (2001). Index construction with formative indicators: An alternative to scale development. Journal of Marketing Research, 38(2), 269-277.

Diamantopoulos, A., Riefler, P., \& Roth, K. (2008). Advancing formative measurement models. Journal of Business Research, 61(12), 1203-1218.

Drew, S. (1997). From knowledge to action: The impact of benchmarking on organizational performance. Long Range Planning, 30(3), 427-441.

Escribano, A., Fosfuri, A., \& Tribó, J. (2009). Managing external knowledge flows: The moderating role of absorptive capacity. Research Policy, 38(1), 96-105.

Falk, R., \& Miller, N. (1992). A primer for soft modeling. Akron, OH: The University of Akron.

Falk, R., \& Miller, N. (1992). A primer for soft modeling. Akron, OH: University of Akron Press.

Flatten, T., Greve, G., \& Brettel, M. (2011). Absorptive capacity and firm performance in SMEs: The mediating influence of strategic alliances. European Management Review, 8(3), 137-152.

Fornell, C. (1987). A second generation of multivariate analysis: Classification of methods and implications for marketing research. In M. Houston (Ed.), Review of Marketing (pp. 407-450). Chicago, IL: American Marketing Association.

Fornell, C., \& Larker, D. (1981). Evaluating structural equation models with unobservable variables and measurement error. Journal of Marketing Research, 39-50.

Fosfuri, A., \& Tribó, J. (2008). Exploring the antecedents of potential absorptive capacity and its impact on innovation performance. Omega, 36(2), 173-187.

Freel, M. (2000). Barriers to Product Innovation in Small Manufacturing Firms. International Small Business Journal, 18(2), 60-80.

Fuchs, P., Mifflin, K., Miller, D., \& Whitney, D. (2000). Strategic integration: competing in the age of capability. California Management Review, 42, 118-147.

Gaiardelli, P., Martinez, V., \& Cavalieri, S. (2015). The strategic transition to services: a dominant logic perspective and its implications for operations. Production Planning \& Control, 26(1415), 1165-1170.

Gebauer, H., Fleisch, E., \& Friedli, T. (2005). Overcoming the Service Paradox in Manufacturing Companies. European Management Journal, 23(1), 14-26.

Gebauer, H., Worch, H., \& Truffer, B. (2012). Absorptive capacity, learning processes and combinative capabilities as determinants of strategic innovation. European Management Journal, 30, 57-73.

Gentry, R., \& Shen, W. (2013). The impacts of performance relative to analyst forecasts and analyst coverage on firm R\&D intensity. Strategic Management Journal, 34(1), 121-130. 
Gómez-Mejía, L., Haynes, K., Núñez-Nickel, M., Jacobson, K., \& Moyano-Fuentes, J. (2007). Socioemotional wealth and business risks in family-controlled firms: Evidence from Spanish olive oil mills. Administrative Science Quarterly, 52(1), 106-137.

Groher, E. (2003). Designing the integration of suppliers in the product development process. München (in German): TCW.

Gustafsson, A., Brax, S., \& Witell, L. (2010). Setting a research agenda for service business in manufacturing industries. Journal of Service Management, 21(5), 557-563.

Hair, J., Ringle, C., \& Sarstedt, M. (2011). PLS-SEM: Indeed a silver bullet. Journal of Marketing Theory and Practice, 19(2), 139-151.

Hair, J., Sarstedt, M., Ringle, C., \& Mena, J. (2012). An assessment of the use of partial least squares structural equation modeling in marketing research. Journal of the Academy of Marketing Science, 40, 414-433.

Henseler, J., Ringle, C., \& Sinkovics, R. (2009). The Use of Partial Least Squares Path Modeling in International Marketing. Advances in International Marketing, 20, 277-319.

Hermann, P., \& Nadkarni, S. (2014). Managing strategic change: The duality of CEO personality. Strategic Management Journal, 35(9), 1318-1342.

Hofstede, G. (1993). Cultural constraints in management theories. The Academy of Management Executive, 7(1), 81-94.

Hu, M., Horng, J., \& Sun, Y. (2009). Hospitality teams: Knowledge sharing and service innovation performance. Tourism Management, 41-50.

Huergo, E., \& Jaumandreu, J. (2004). How does probability of innovation change with firm age? Small Business Economics, 22(3-4), 193-207.

Hulland, J. (1999). Use of partial least squares (PLS) in strategic management researcht: A review of four recent studies. Strategic Management Journal, 20(2), 195-204.

Hurmellina-Laukkanen, P., Sainio, L.-M., \& Jauhiainen, T. (2008). Appropriability regime for radical and incremental innovations. R\&D Management , 38(3), 278-289.

Jansen, J., Van Den Bosch, F., \& Volberda, H. (2005). Managing potential and realized absorptive capacity: how do organizational antecedents matter? Academy of Management Journal, 48(6), 999-1015.

Johne, A., \& Storey, C. (1998). New service development: A review of the literature and annotated bibliography. European Journal of Marketing, 32(3/4), 184-251.

Kelley, S. (1993). Discretion and the Service Employee. Journal of Retailing, 69(1), 104-127.

Kogut, B., \& Zander, U. (1992). Knowledge of the firm, combinative capabilities, and the replication of technology. Organization Science, 3(3), 383-397.

Lagacé, D., \& Bourgault, M. (2003). Linking manufacturing improvement programs to the competitive priorities of Canadian SMEs. Technovation, 23, 705-715.

Laursen, K., \& Salter, A. (2006). Open for Innovation: The Role of Openness in Explaining Innovation Performance among U.K. Manufacturing Firms. Strategic Management Journal, 27, 131-150. 
Liao, S., Fei, W., \& Liu, C. (2008). Relationships between knowledge intertia, organizational learning and organization innovation. Technovation, 28(4), 183-195.

Lusch, R., Vargo, S., \& O'Brien, M. (2007). Competing through service: Insights from servicedominant logic. Journal of Retailing, 83(1), 5-18.

Madrid-Guijarro, A., Garcia, D., \& Van Auken, H. (2009). Barriers to Innovation among Spanish Manufacturing SMEs. Journal of Small Business Management, 47(4), 465-488.

Maes, J., \& Sels, L. (2014). SME's Radical Product Innovation: The Role of Internally and Externally Oriented Knowledge Capabilities. Journal of Small Business Management, 52(1), 141-163.

Melton, H., \& Hartline, M. (2013). Employee collaboration, learning orientation, and new service development performance. Journal of Service Research, 16(1), 67-81.

Moreno, A., \& Casillas, J. (2008). Entrepreneurial orientation and growth of SMEs: A causal model. Entrepreneurship theory and practice, 32(3), 507-528.

Muscio, A. (2007). The impact of absorptive capacity on SMEs' collaboration. Economics of Innovation and New Technology, 16(8), 653-668.

Muscio, A. (2007). The impact of absorptive capacity on SMEs' collaboration. Economics of Innovation and New Technology, 16(8), 653-668.

Neely, A. (2008). Exploring the financial consequences of the servitization of manufacturing. Operations Management Research, 1(2), 103-118.

Nijssen, E., Hillebrand, B., Vermeulen, P., \& Kemp, R. (2006). Exploring product and service innovation similarities and differences. International Journal of Research in Marketing, 23, 241-251.

Noburn, D., \& Birley, S. (1988). The top management team and corporate performance. Strategic Management Journal, 9(3), 225-237.

Ordanini, A., \& Parasuraman, A. (2011). Service innovation viewed through a service-dominant logic lens: A conceptual framework and empirical analysis. Journal of Service Research, 14(1), 323.

Ordanini, A., \& Parasuraman, A. (2011). Service Innovation Viewed Through a Service-Dominant Logic Lens: A Conceptual Framework and Empirical Analysis. Journal of Service Research, 14(1), 3-23.

Page, A., \& Schirr, G. (2008). Growth and development of a body of knowledge: 16 years of new product development research, 1989-2004. Journal of Product Innovation Management, 25(3), 233-248.

Prajogo, D., \& McDermott, C. (2014). Antecedents of service innovation in SMEs: Comparing the effects of external and internal factors. Journal of Small Business Management, 52(3), 521540 .

Raymond, L., \& St-Pierre, J. (2010). R\&D as a determinant of innovation in manufacturing SMEs: An attempt at empirical clarification. Technovation, 30(1), 48-56.

Ringle, C., Wende, S., \& Becker, J. (2015). SmartPLS 3. Boenningstedt: SmartPLS GmbH. Retrieved from http://www.smartpls.com 
Ringle, C., Wende, S., \& Becker, J.-M. (2014). SmartPLS 3. Hamburg, Germany: SmartPLS. Retrieved from http://www.smartpls.com

Rothaermel, F., \& M, A. (2009). Ambidexterity in technology sourcing: The moderating role of absorptive capacity. Organization Science, 20(4), 759-780.

Schimmer, M., \& Brauer, M. (2012). Firm performance and aspiration levels as determinants of a firm's strategic repositioning within strategic group structures. Strategic Organization, 10(4), 406-435.

Schneider, B., \& Bowen, D. (1984). New Service Design, Development and Implementation and the Employee. In W. George, \& C. Marshall (Eds.), Developing New Services (pp. 82-101). Chicago: American Marketing Association.

Slater, S., \& Narver, J. (1995). Market orientation and the learning organization. The Journal of Marketing, 63-74.

Slater, S., \& Narver, J. (1995). Market Orientation and the Learning Organization. Journal of Marketing, 59, 63-74.

Sousa, C., Lengler, J., \& Martínez-López, F. (2014). Testing for linear and quadratic effects between price adaptation and export performance: The impact of values and perceptions. Journal of Small Business Management, 52(3), 501-520.

Spring, M., \& Araujo, L. (2009). Service and products: rethinking operations strategy. Journal of Operations \& Production Management, 29(5), 444-467.

Storey, C., Cankurtaran, P., Papastathopoulou, P., \& Hultink, E. (2016). Succes factors for service innovation: A meta-analysis. Journal of Product Innovation Management.

Teece, D. (1980). Economics of scope and the scope of the enterprise. Journal of Economic Behavior and Organization, 1(3), 223-247.

Terziovski, M. (2010). Innovation practice and its performance implications in small and medium enterprises (SMEs) in the manufacturing sector: A resource-based view. Strategic Management Journal, 31, 892-902.

Tether, B. (2002). Who co-operates for innovation, and why An empirical analysis. Research Policy, 31, 947-967.

Tether, B. (2002). Who co-operates for innovation, and why: an empirical analysis. Research Policy, 31(6), 947-967.

Tsai, W. (2001). Knowledge transfer in intraorganizational networks: Effects of network position and absorptive capacity on business unit innovation and performance. Academy of Management Journal, 44(5), 996-1004.

Tzokas, N., Kim, Y., Akbar, H., \& Al-Dajani, H. (2015). Absorptive capacity and performance: The role of customer relationship and technological capabilities in high-tech SMEs. Industrial Marketing Management, 47, 134-142.

Van Wijk, R., Van den Bosch, F., \& Volberda, H. (2001). The impact of knowledge depth and breadth of absorbed knowledge on levels of exploration and exploitation. Washington, DC: Paper presented at the annual meeting of the Academy of Management. 
Vargo, S., \& Lusch, R. (2004). Evolving to a new dominant logic for marketing. Journal of Marketing, 68(1), 1-17.

Volberda, H., Foss, N., \& Lyles, M. (2010). Perspective - Absorbing the Concept of Absorptive Capacity: How to Realize Its Potential in the Organization Field. Organization Science, 21(4), 931-951.

Voss, C., Johnston, R., Silvestro, R., Fitzgerald, L., \& Brignall, T. (1992). Measurement of innovation and design performance in services. Design Management Journal Winter, 40-46.

Wiklund, J., \& Shepherd, D. (2005). Entrepreneurial oeintation and small business performance: A configurational approach. Journal of Business Venturing, 20(1), 71-91.

Wiklund, J., \& Shepherd, D. (2005). Entrepreneurial orientation and small business performance: A configurational approach. Journal of Business Venturing, 20(1), 71-91.

Zahra, S., \& Garvis, D. (2000). International corporate entrepreneurship and firm performance: The moderating effect of international environmental hostility. Journal of Business Venturing, 15(5), 469-492.

Zahra, S., \& George, G. (2002). Absorptive Capacity: A Review, Reconceptualization, and Extension. The Academy of Management Review, 27(2), 185-203.

Zhang, M., Macpherson, A., \& Jones, O. (2006). Conceptualizing the learning process in SMEs Improving innovation through external orientation. International Small Business Journal, 24(3), 299-323. 


\section{FIGURES}

\section{Figure 1: Structural model}

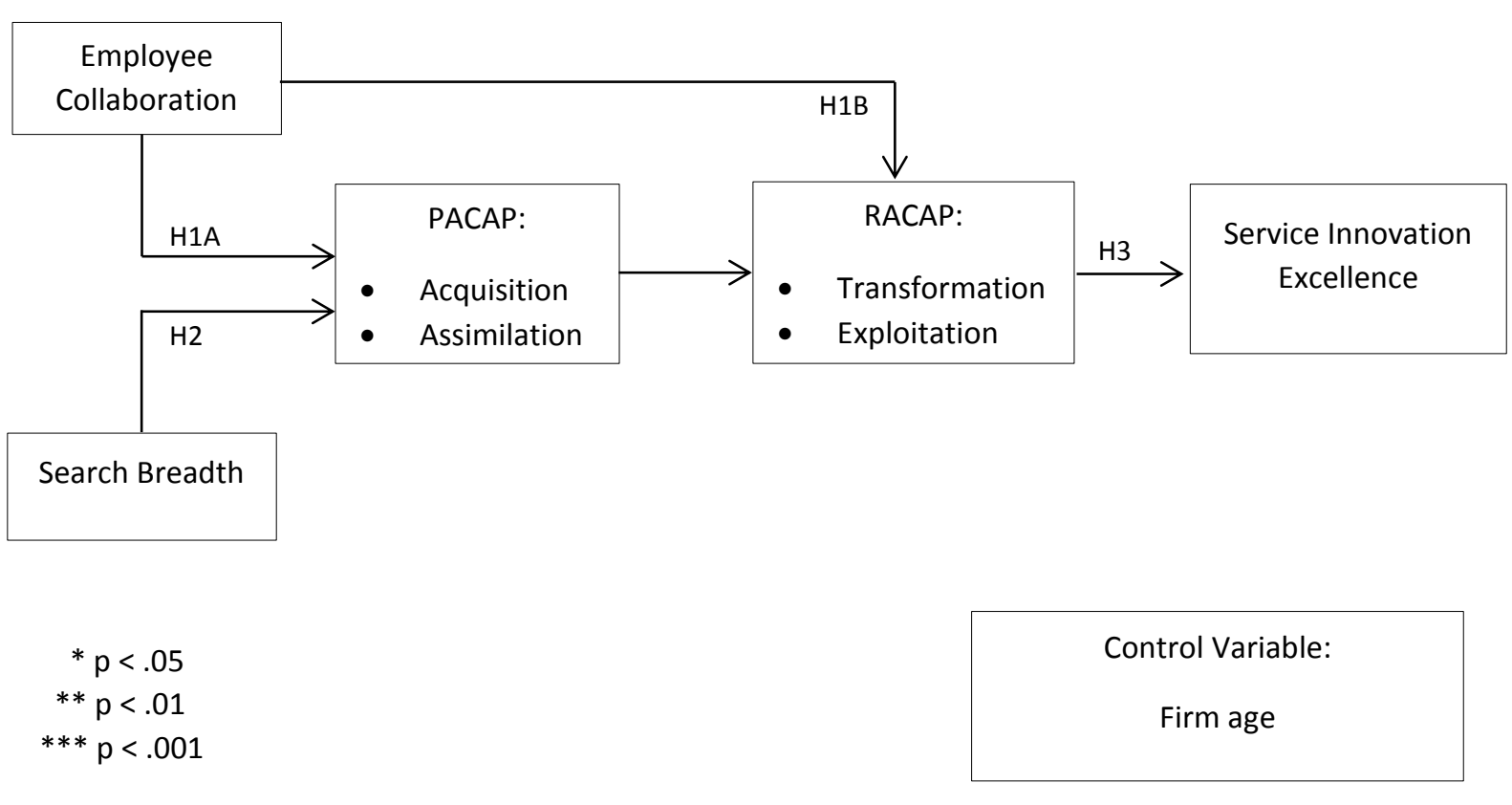

Figure 2: Results

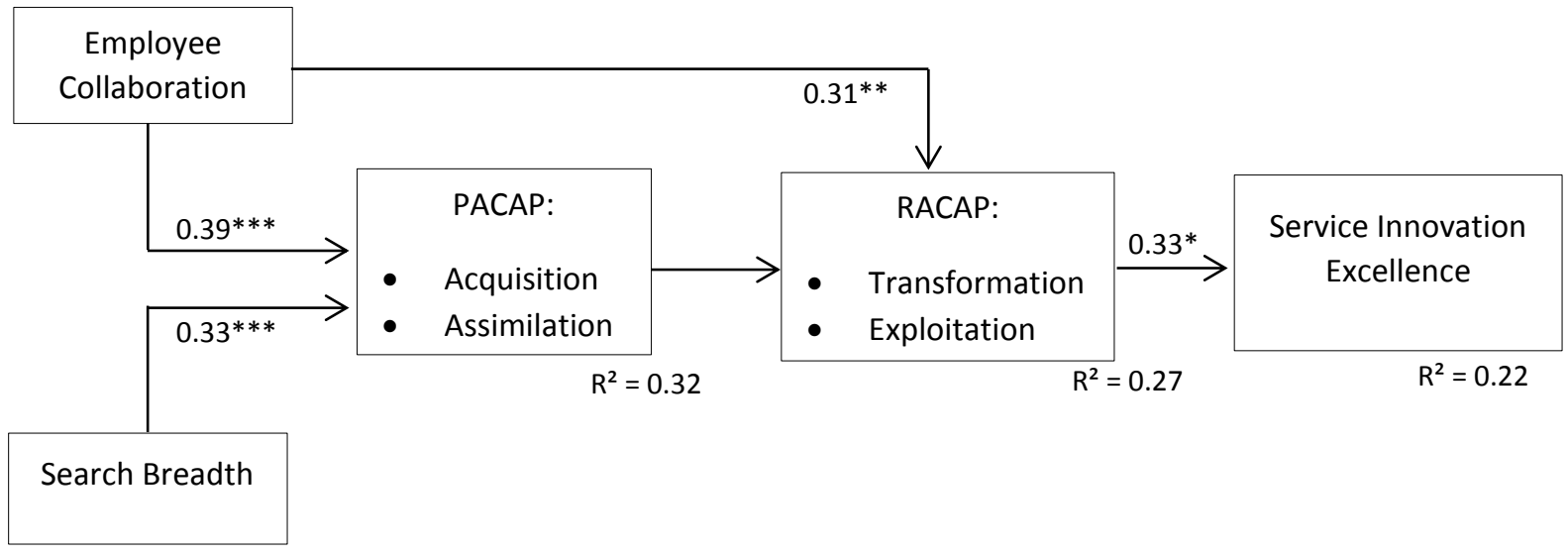

\footnotetext{
$* \mathrm{p}<.05$

$* * p<.01$

$* * * p<.001$
}

Control Variable:

Firm age 


\section{TABLES}

Table 1: Measurement Scales

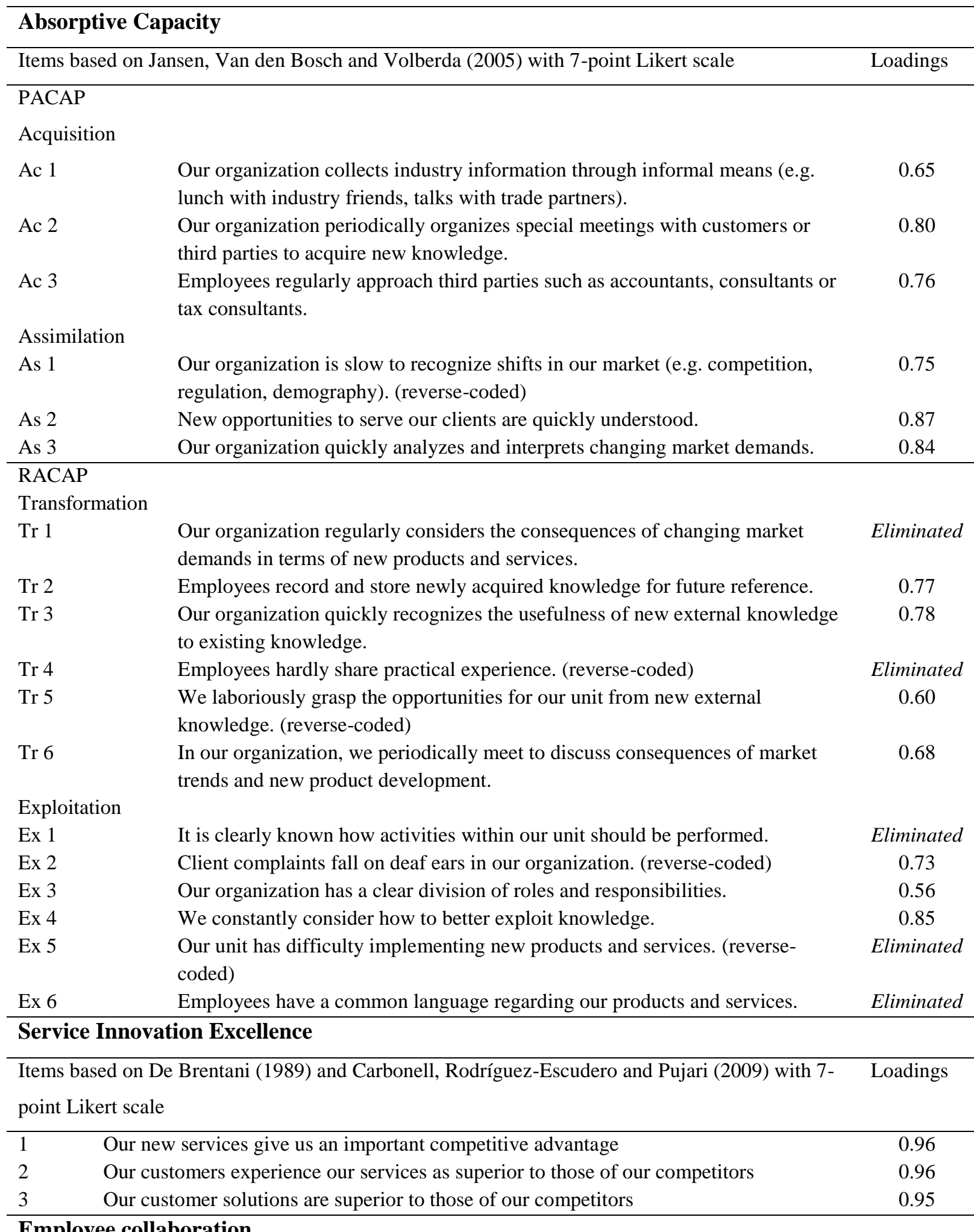

\begin{tabular}{lcc}
\hline Items based on Ordanini and Parasuraman (2011) with 7-point Likert scale & Loadings \\
\hline 1 & Employees are actively engaged in generating and screening ideas for new services. & 0.77
\end{tabular}


Table 2: Reliability, validity and measurement model

\begin{tabular}{lcccc}
\hline Reflective Factor & $\begin{array}{c}\text { Number } \\
\text { of Items }\end{array}$ & $\begin{array}{c}\text { Range of } \\
\text { Loadings }\end{array}$ & $\begin{array}{c}\text { Average Variance } \\
\text { Extracted }\end{array}$ & Composite Reliability \\
\hline Search breadth & 1 & 1 & 1 & 1 \\
Employee Collaboration & 3 & $0.77-0.88$ & 0.71 & 0.88 \\
Acquisition & 3 & $0.65-0.80$ & 0.55 & 0.78 \\
Assimilation & 3 & $0.75-0.87$ & 0.68 & 0.86 \\
Transformation & 4 & $0.60-0.78$ & 0.51 & 0.80 \\
Exploitation & 3 & $0.56-0.85$ & 0.52 & 0.76 \\
Service Innovation Excellence & 3 & $0.95-0.97$ & 0.92 & 0.97 \\
Firm Age & 1 & 1 & 1 & 1 \\
\hline Formative Factor & \multicolumn{7}{c}{ Number of items } & Range of Weights & Range of VIFs \\
\hline Potential Absorptive Capacity & \multicolumn{7}{c}{$0.439-0.803$} & $1.164-1.316$ \\
Realized Absorptive Capacity & & 2 & $0.476-0.641$ & $1.597-2.225$ \\
\hline
\end{tabular}

Table 3: Correlations and Square Root of Average Variance Extracted in Diagonal

\begin{tabular}{lcccccccc}
\hline Variable & 1 & 2 & 3 & 4 & 5 & 6 & 7 & 8 \\
\hline 1. Employee Collaboration & $\mathbf{0 . 8 4}$ & & & & & & & \\
2. Search Breadth & 0.22 & $\mathbf{1}$ & & & & & & \\
3. Acquisition & 0.36 & 0.40 & $\mathbf{0 . 7 4}$ & & & & & \\
4. Assimilation & 0.33 & 0.24 & 0.22 & $\mathbf{0 . 8 2}$ & & & & \\
5. Transformation & 0.49 & 0.32 & 0.33 & 0.52 & $\mathbf{0 . 7 1}$ & & & \\
6. Exploitation & 0.37 & 0.22 & 0.33 & 0.18 & 0.60 & $\mathbf{0 . 7 2}$ & & \\
7. Service Innovation Excellence & 0.04 & 0.06 & 0.01 & 0.20 & 0.26 & 0.37 & $\mathbf{0 . 9 6}$ \\
8. Firm Age & 0.01 & -0.06 & 0.16 & -0.02 & 0.01 & -0.15 & -0.35 & $\mathbf{1}$ \\
& & & & & & & & \\
\hline
\end{tabular}

